\title{
The Representation Study of Educational Value in Saur Matua Customs at the Death Ceremony as the Identity of Batak Toba Community in Bukittinggi City
}

\author{
Dina Astuty ${ }^{1 *}$, Indrayuda ${ }^{2}$ \\ ${ }^{1}$ Postgraduate Program of Universitas Negeri Padang, Padang, Sumatra Barat 25131, Indonesia \\ ${ }^{2}$ FBS Universitas Negeri Padang, Padang, Sumatra Barat 25131, Indonesia \\ *Corresponding author. Email: dina.astuti@gmail.com
}

\begin{abstract}
The traditional of saur matua is was a traditional ceremony for the dead has given birth to grandchildren of both boys and girls. Saur means complete/perfect in kinship, has a grandchild. Because the deceased is perfect in kinship so it must be implemented perfectly. This study aims to analyze the educational values contained in the structure of the saur matua traditional procession that identity of the Batak Toba community in the city of Bukittinggi. This study uses a qualitative method. The informants in the this study were Napi najolo parsinabung, Hula-hula, Dongan Tubu, Boru, Ikatan Punguan Marga Batak administrators with Batak Toba community who carry out the Saur Matua traditional ceremony. The result of this study that the saur matua has been done by the Batak Toba community who live in Bukittinggi. Saur matua custom is closely related to cultural teachings and traditional Batak teachings in the form of moral education, religious, and social. This is proven that the Batak Toba community can be guided by a series of Saur Matua traditional ceremonies to lead a wise group life in acting, coustesy, togetherness in group life, have good morals and be considerate towards others.
\end{abstract}

\section{Keywords: Saur Matua, Identity}

\section{INTRODUCTION}

The process of life and every thing happens make people happy starting from birth, achievement and marriage, there is one life process that brings sorrow in the family even to foreign countries, namely death. The definition of death is not life; does not ignite and death itself implies the journey of human life that is over, so it does not need to be feared because they do not know when but certainly death will come to us one by one.

Life consists of two poles of conflict, between "life" and "death", which became the basic understanding of humans since ancient times as a form of dualism of the existence of life to the present. Death is the end of the journey of human life. So death is basically an ordinary thing that should not be feared, because sooner or later it will pick up the lives of each human being. But it is natural that death is not the main desire of humans. According to the Toba Batak people, humans are a whole subject because of three important components: tondi, roha, and pamatang (Nainggolan 2012: 24). Humans have a goal to reach hamoraon, hagabeon and hasangapon. These three life goals are a dream for everyone. Meanwhile, they also believe that life will end in death. However, death never separates them from family and also their relationship with family. Various efforts will always be taken by humans to avoid death, at least slowing down the coming death. Ideally, the death comes at a very old age.

The death ceremony of the Toba Batak community has a deep meaning for the Batak community, so that the Batak Toba community views the death ceremony as having a customary status of death, that is, dying before they are not married and dying after marriage. Based on an interview with Mr. Amang Manik who is a representative of the board of the Batak Marga Association in the City of Bukittinggi (interview April 4, 2019) revealed that dying before marriage and after marriage, death ceremonies after marriage one of them is mate saur matua, that is, the person who suffered this death is considered has reached his life goal (gabe). Because, concerned died in a state where he already has pahompu (grandchildren) of all his children. In the Toba Batak community, death at a very old age is the most desirable death. Especially when the dead have married all their children and have grandchildren of their children, such as the death of Saur Matua.

Saur matua's death is a person who has died has children of grandchildren of both boys and girls. Saur means complete / perfect in kinship, having children and grandchildren. Because the deceased is perfect in kinship so it must be carried out perfectly. Saur matua traditional ceremony among the Toba Batak community in 
Bukittinggi City has several stages including a ceremony in dijabu (at home) and maracage ceremony (in the yard).

Cultural identity is the identity that is owned by a group of people obtained from the group's formation through the process of interaction that is done every day in his life in society and then forms a special pattern that defines the group. Identity is used as identification that has meaning in the culture created by the people who created it. An identity as a special character inherent in each culture, so that it can be distinguished between one culture with another culture. Culture that is lifted into an identity of a culture is not created just like that, but requires a long time to be known, recognized, obeyed and implemented in the environment.

Based on interviews with Mr. Amang Lubis who is the chairman of the Batak Punguan Marga Association or better known as IPMB (interview, April 4, 2019) revealed that "the Saur Matua traditional ceremony is a ceremony part of the Toba Batak community life that has existed from the past until now so the Saur traditional ceremony matua has many important values that are very meaningful to the Batak community in the City of Bukittinggi ".

Nowadays many Toba Batak people migrate out of their homeland, namely North Sumatra, some migrate to Java, to Aceh Province, and some even migrate to Bukittinggi City, West Sumatra. Based on an interview with Mr. Amang Manik (interview, April 4, 2019) revealed that "although many Toba Batak people have migrated in general if they experience misfortune such as death they always carry out customary ceremonies of death, one of which is the traditional ceremony of saur matua. Especially in Bukittinggi City, the Saur Matua traditional ceremony is always held if there is one of the Saur Matua who dies in Bukittinggi City. Saur matua traditional ceremonies are carried out in accordance with the stages of traditional ceremonies established by the ancestors of the Toba Batak people.

Toba Batak community cohesiveness in carrying their original customs wherever they go makes this death custom something unique from the attitudes and actions of community life for the Toba Batak community migrants. Even though they have become members of the community in West Sumatra, especially in Bukittinggi City, Agam Regency, the Batak Toba people have never abandoned this death custom, even though they are not in the Batak land.

\section{METHOD}

This research was conducted in the City of Bukittinggi, Agam Regency. This research uses a qualitative approach because it tries to express and understand the reality that is in the field as it is, with the type of research being the descriptive type in which the research results are presented using words. The type of data used is primary data and secondary data. The method used is descriptive. According to Ratna (2012: 53), descriptive method is a method used to describe facts which are then followed by analysis.

The data from this research are words or information related to the study of the representation of educational value in the saur matua custom at the death ceremony as the identity of the Toba Batak people in Bukittinggi City, which was obtained through information directly involved in the saur matuaa traditional ceremony at the death ceremony. Researchers determine the informants in this study, namely: Prisoners Najolo Parsinabung, Hula-hula, Dongan Tubu, Boru, members of the Batak Punguan Marga Association and the Toba Batak people who carry out the Saur Matua traditional ceremonies.

The instrument used is the researcher himself so the researcher must be "valued". The tools used by researchers to collect data in this study were (1) a photo camera used to document images of death ceremonies from the ceremony inside the house or on the lawn. (2) Handycam / DSLR is used to help make a video in analyzing the procession structure in the Saur Matua traditional ceremony.

\section{RESULTS AND DISCUSSION}

\subsection{Representation of Saur Matua Customary Ceremony at Death Ceremony in Bukittinggi City}

Culture has cultural values that guide the community to act in the face of various life problems. So that in the end the concept of culture is more as a guideline for evaluating the symptoms understood by the perpetrators of the kebadayaan. In culture, meaning is not individual but public, when the meaning system then becomes the collective possession of a group.

Geetz (translation of Roger M. Kessing 1999: 68-69) gives the notion of culture into two elements namely culture as a cognitive system, part of the value system. Cognitive systems or systems of meaning are patterns of representation (patterns of), whereas value systems are representations of patterns for (pattern for). To combine "patterns from and patterns for" or congenitive systems with value systems, namely the link between translating systems of knowledge and meaning, Geetz said it lies in the symbol system. So, the pattern of action, culture is a set of human knowledge that contains models that are selectively used to interpret, encourage, and create actions or in other senses as guidelines for action. While the pattern for cultural action is what is done and can be seen by everyday people as a real existence or in another sense as a form of action.So, the pattern of action, culture is a set of human knowledge that contains models that are selectively used to interpret, encourage, and create actions or in other senses as guidelines for action. While the pattern for cultural action is what is done and can be seen by everyday people as a real existence or in another sense as a form of action.

\section{Ceremony before death by Feeding ailing Parent (Man repeat).}

In the life of the Toba Batak people, if there is an elderly person who suffers from an illness that is difficult to cure, then his descendants and the whole family conduct a special traditional event called manulang (feeding). This event was done by eating a plate of two containing side 
dishes fed by the eldest child (the oldest child) to his parents while stating that they were anxious and worried about their parents' condition and prayed that their parents would recover soon and continue to pray for the whole family from each of them. children and grandchildren so that they can have eternal life, long life, easy fortune. After repeating sick parents give advice to their children and at that time parents also discuss the distribution of his inheritance when someday he left this world and closed with prayer. The next day the Hula-hula (uncle of the parents) came with Dengke (Goldfish) and one sheet of Ulos (Batak traditional cloth) placed on the shoulders (shoulders) of the parents. The meaning of carrying ulos cloth is the meaning of giving food and ulos to heal quickly, long life can guide their offspring to prosper in God.

When a parent is declared dead, then the whole family cries (Mangandungi) and laments the departure of his parents who have died worldwide. mangandungi is a kind of oral literature that contains a feeling of feelings to mourn the bodies of loved ones (Nalom Siahaan, 1982: 70). The body is then injected with preservative medicine in certain parts of his body by the health authorities so that the body of the dead body is of use to wait for the brothers and sisters and the stages of the customary implementation that will be carried out by wearing the best clothes and covered with ulos cloth placed in the guest room.

At that time a public consultation was held or better known as mangarapot. Mangarapot was carried out by the man of the deceased parent and another brother of the Hula-Hula, Boru Dongan Tubu, Raja Adat, Parsuhuton. Then the division of tasks was held by Dalihan Na Tolu. In managing the lives of the Toba Batak people who when playing an important role are Dalihan Na Tolu (DNT). The role of Dalihan Na Tolu in the lives of the Toba Batak people is very much needed. In accordance with Marbun and Hutapea 45: 1987 revealed that the role of a Dalihan $\mathrm{Na}$ Tolu is as a guide and decision maker in every traditional activity in the Toba Batak. The division of tasks begins with those who go to invite (Manggokhon). or one village, family mates, relatives who were observed.) Suhut's (grieving family) ordered chests, prepared livestock food to eat at the ceremony, and who worked (Marhobas) was Boru.

\section{The Implementation Ceremony of the ceremony of the death of Saur Matua}

The event of Saur Matua ceremony is divided into two, namely the ceremony at home (dijabu) and the ceremony in the yard (marhalaman), namely:

a) Ceremony at home (dijabu)

1) A program of consolation from a close family, dongan sahuta, dambat natulo, churc

Before the ceremony at home the corpse was laid in the living room (jabubona). In front of the room of the deceased parents or in front of the children's room covered with sibolang ulus known as mengulosi while mangandungi. Hodges shows that in chanting the andung (lamentation) the pangandung feels that there is a relationship that can each be maintained even if the body of the deceased is dead. One of the human components, it is believed to be a component that is still alive so that it can still carry out communicative relations through the andung-andung. Hodges also explained that lamentation also functions as a kind of communication channel between this world and other worlds so that requests from this world are submitted to the ancestors and their good fortune / blessings can be given to the living (Hodges, 2009: 9). For the Toba Bataks, the tradition of singing andung is considered part of adat and is included in a very important category. Sihombing explained the importance of this tradition with one assumption, "if a child does not want to take care of his parents who died then that person is considered" ignorant of adat "(Sihombing, 1986: 122). The importance of tradition is even related to how deeply one understands Batak culture.

This activity lasted until the evening, especially gondang music which was first played or sounded to illustrate its origin in this world, both human beings, wealth, wealth, honor, and positions will all return to God. This ceremonial activity took place for several days before the procession was held every night while filled with singing and dancing tor-tor or better known as menotor all elements of Dalihan $\mathrm{Na}$ Tulo which aims to determine a good day before being buried.

\section{2) Insert the body into the coffin}

In the morning there was a ceremony to enter the corpse into the trunk or casket by Dongan Sabutuha, Hulahula, and Boru

\section{3) Purchase capulul or ulos sibolang hulos to the wife / husband left behind.}

There is an official recognition of the position that someone officially worshiped by a Batak has become a widower or widow who is placed on the shoulder. The name of the ulos is Ulos Sampos or Ulos Tali Tali. Then hula give ulos summon to all descendants, by attaching the ulos momentarily alternately on the shoulders of each of the oldest boys to the youngest, the last being given back to the oldest boy along with the words of blessing. The same is true of the hula, the bone of each hasuhuton. Then each woman from the group of bone manortor while upholding boras sipiritondi which is plain flour rice which means giving a blessing and strengthening kinship, and then handed over to the hasuhuton.

Then the suhut discussed the hula hula by giving the ulos replacement with some money to the hula hula. Accompanied by margondang (music) activities until the martor tor (dancing) the meaning for suhut (family party) dancing and giving money is to unite the intention to bury the dead man's husband or parent's event going well and smoothly to completion. In all the lives of the Toba Batak people, art is inherent and becomes a part of their life activities. Various forms of art grow and develop in the Batak community such as hymns, songs of worship, and spiritual music and worship music in religious activities 
(Christianity).Using Bourdieu's perspective, music is a habitus of Batak people (Prasetya, et al, 55: 2011).

In the afternoon the traditional ceremony of pandungoi is carried out by feeding the abandoned spouse, children and all relatives, and followed by the ukap hombung event (exploring the inheritance of searching for the late life by giving respect to the brothers and sisters of the mother in the form of money, objects, buffalo, rice fields or gold while accompanied by gondang Batak music.

Then the suhut discussed the hula hula by giving the ulos replacement with some money to the hula hula. kemuin is accompanied by margondang activities (music), pestilence, manotor (dancing), the meaning of which is for the suhut to dance and give money or known as jambar hepeng.

\section{b) ceremony at the yard (maralaman)}

All families gather and the Toba Batak people gather at the yard of the house. For the Toba Batak people, culture is not just a habit or social order, but something that covers all dimensions of physical and spiritual life, in the present and future, relationships with others and with "the creator". (J.S.Aritonang, 43: 1988). The family and the guests present began the consolation of the Church, which was the official service. After the church program was over, the church administration ordered Boru to lift the coffin to the terrace or courtyard accompanied by church music.Crates are placed in front of the courtyard house. His wife and children who had died in customary clothes stood beside the coffin in the order of the largest children and the oldest grandchildren to the last children and grandchildren. The pastor opened the worship service with the word and accompanied by the gondang music church songs for comfort and strength for the families left behind and for Debata (God) to bless this event from beginning to end. After the resurrection of the church, we had a meal together for everyone at the ceremony.

After that, it was continued with margondang activities from demagoguery, sabutuha, Hula-hula, Ale- ale, bringing ulos and jambar (food) while circling the suhut (family) and reciprocating in return giving money to those who gave them ulos sign changes ulos given while marnortor accompanied by gondang Batak music.

After all the Batak traditional events were finished, the closing ceremony of the church officials began with singing and praying, then the coffin was closed and nailed while accompanied by the weeping tears of the couple left behind or the family left behind and escorted him to the cemetery also held a service to release the corpse before being put into the ground. by Father Reverend.

\section{Events after the Saur Matua traditional burial}

Arriving all parties Suhut, Hasuhutan, Dongan Sabutuha, Hula-Hula, Boru at the funeral home they ate together with a picture of the parties mentioned earlier as a thanksgiving for the successful implementation of the burial of parents. Then the ceremony said that the Hombung is an event to give some of the assets left by the deceased (sharing the inheritance) to give to the hula-hula. some according to their respective positions as an expression of respect for the Hula-Hula of parents who died in the form of money, gold, heritage or jewelry.

\subsection{The Value of Education in Saur Matua Customs as the Identity of the Toba Batak Community in Bukittinggi City}

Saur matua traditional ceremony in its implementation really requires a large cost, a long time, and very complicated. But even so the Toba Batak people in Bukittinggi still carry out the Saur Matua traditional ceremony, sometimes they want to be in debt or borrow money for the ceremony. Seeing this reality basically the dynamic nature possessed by the Toba Batak people in Bukittinggi City is the background of people's lives to actualize themselves so that the Toba Batak people always maintain the cultural ties and customary ties of Dalihan $\mathrm{Na}$ Tolu. Saur matua traditional ceremonies are maintained wherever they are, both those who live in Batak land and those who live in overseas areas. These ties are owned by the Toba Batak community. They individually tie the Batak Toba community individually to a very high group life. Customs and traditions of ancestors who have passed down from generation to generation obligate the Toba Batak people to respect their parents during their lifetime or when they die. The Toba Batak community in the city of Bukittinggi felt it was important to establish good relations with the custom of Dalihan $\mathrm{Na}$ Tolu, which was realized with a death ceremony to honor parents who died. Thus the desire to respect ancestors and unite descendants will be realized. To pursue the basic ideals in the life of the Toba Batak people in Bukittinggi, they believe that when the Saur Matua traditional ceremony has been carried out, the basic ideals of a person have been achieved and the custom of a child's debt to parents has been considered over. This is what makes the Saur Matua traditional ceremony have very important educational values that are role models in the lives of the Toba Batak people.

Ali (1979: 21) said "the value of education is the values that prepare students for their role in the future through guidance, teaching, and training. Haryadi (in Suwondo, 2006: 73) also defines the value of education as "a teaching which is of great value according to the size of education which is a bridge towards the achievement of educational goals". Nurgiantoro (2007), divides educational values into three types, namely religious education values, moral education values, and social education values.

The educational values contained in the activities of the Saur Matua traditional ceremonies can be seen from several stages of the composition of the Saur Matua traditional ceremonies in the city of Bukittinggi including:

\section{a. The Value of Religious Education}

The consolation program of the Church is an official service which explains that the life of the world is only a temporary life. Nurgiantoro (2007: 327) said "Religion is an awareness that is deeply symptomatic in the human 
heart. Religious see aspects in the depths of the heart, the vibration of the conscience of the person, the totality of the depth of the human person, Religion not only concerns the outward aspect of life but also involves the total self as a total person in the integration of relations into the oneness of God ".

It's good during our lives we must do good so we can clean the hearts and minds of the pure heart in the heart in living a life that is in line with the teachings of Christianity, Dalihan Na Tolu customs and the concept of community life. The idea of spiritual maturity they got after reflecting on the saur matua ceremony became a form of thanksgiving from all the children and grandchildren of people who died to God, no longer to the spirits of the ancestors.

The consolation program of the Church is an official service which explains that the life of the world is only a temporary life. It's good during our lives we must do good so we can clean the hearts and minds of the pure heart in the heart in living a life that is in line with the teachings of Christianity, Dalihan Na Tolu customs and the concept of community life. The idea of spiritual maturity they got after reflecting on the saur matua ceremony became a form of thanksgiving from all the children and grandchildren of people who died to God, no longer to the spirits of the ancestors.

Religious values can also be seen during the jambar hepeng ceremony and jambar eating together when returning from the burial site. This shows gratitude and thanks to God who has bestowed abundant wealth on humanity.

\section{b. Moral Education Values}

On the occasion of the bone manortor (the deceased mother's brother), cover the live yeast ulos directly to the body of the corpse. Ulos was developed on top of a coffin, as a last sign of affection. Then also performed manotor. Manortor is done while approaching from each party who has attended the ceremony, as a sign of respect as well as asking for blessing. The value contained in the ceremony of the death of Saur Matua in the Toba Batak community in Bukittinggi City is from the advice given to Dalian Na Tolu about how the family should be able to be kind, polite and friendly and love her new family later as she has been cared for by her family so far.

Because the values of life that his parents have taught him from birth to birth and will get married must be good values, so the child must be able to maintain and practice these values well too. Likewise, the norms that are applied to him from birth to adulthood are norms that are full of goodness, and high dignity which he hopes can later be applied back to his children later.

Moral is related to human's noble nature, fighting for human rights and dignity (Nurgiantoro, 2007: 321). This moral value is more related to the behavior of our daily lives. It can be said that the value of moral education shows the rules of behavior and customs of an individual from a group that includes behavior. In this case Nurul Zuriah (2008: 25) also revealed that "the problem and development of moral education in Indonesia, one of which is moral education, aims to instill a set of values that characterize Indonesian people as a whole that harmonizes the values of religion and culture (ideology, science, and so on).

There is no expectation that parents expect from what has been given to their children other than the happiness of seeing their child grow up and succeed in carrying out his life until the child is married. Religious values taught for example diligent worship, practice what is contained in the holy book. Likewise with the norm, which regulates how to live individually or in society. These norms will later give birth to good values for life. This saur matua Death Ceremony will eventually give a positive meaning to the child to arrange his life better in carrying out the customs.

This of course will continue to be developed to her children as a legacy from her parents and certainly cannot be replaced by anything. This tradition is carried out with the hope that the child will not forget the hard work of the parents in raising him and will continue to maintain the manners and manners taught by parents to him.

\section{c. The value of social education}

All members of the community in their community have that tradition so that everyone has the right to that tradition. Nur Uhbiyati (2007: 20) said "the purpose of social education is to educate children to be able to adjust to the life together and take part actively in the life together.

The ceremony of the death of Saur Matua in the Batak community also belongs to the Toba Batak community, one of which is in Bukittinggi City and everyone who belongs to the community has the right to do so. The social value at the death ceremony is clearly seen in the implementation of the Saur Matua ceremony because it is not possible for a person to be able to perform this traditional ceremony without needing help from other family members.

This can be seen starting from the Manggarapot ceremony which requires many parties to conduct deliberations. Mangarapot means looking for relatives and establishing intimacy, between people and ready to help in making decisions. There is cooperation between the family and the community starting from the manggokhon (going to invite) and preparing animal feed to be eaten during the ceremony. Saur matua traditional ceremonies make wise group life in action, togetherness in group life, noble morals and tension for others.

\section{CONCLUSION}

Saur matua traditional ceremony consists of three stages of the ceremony, starting from the ceremony before death by repeating, then the post-death ceremony which consists in the house and in the yard. The ceremony in the house begins with mangandungi (lamenting), with advice from Dalihan Na Tolu, mangulosi, margondang, manotor, inserting the body into the coffin, analyzing said hombung and jambar hepeng. The ceremony in the yard is to listen to an official service from the family and deliver the body 
to the burial place. And the last is the ceremony after the funeral of Saur Matua custom with jambar and said hombung to distribute inheritance to the families left behind.

Saur matua traditional ceremony has educational values that are very meaningful for the Toba Batak community in Bukittinggi. The values of education can be seen from: First, the value of religious education that teaches that life must be good in order to clean the hearts and sacred thoughts of the heart in the heart to live a life that is in line with Christian teachings, Dalihan Na Tolu customs and the concept of community life and have gratitude for the fortune of God.

Second, the value of moral education which shows that every parent teaches how the family should be able to be kind, polite and friendly and love the family. Third, the value of social education that teaches Toba Batak people in Bukittinggi City to be wise in acting, togetherness in group life, noble morals and tension towards others.

\section{ACKNOWLEDGMENTS}

Thank you very much, thank you to the Director of the Postgraduate Universiats field of study and the Head of UNP's Bachelor of Social Sciences Education. Thanks to the help of all the research I have done. For the help and motivation of all parties this article can be improved and at the seminar in this activity.

\section{REFERENCES}

[1] Ali, Muhammad. 1987. Educational Procedural and Strategic Research. Bandung: Space.

[2] Aritonang, J.S. (1988). History of Christian Education in the Batak Land. Siantar

[3] Nainggolan, Togar. 2012. Toba Batak: History and religious transformation. Medan: Bina Media * Pioneer.

[4] Nurgiyantoro, Burhan. 2007. Theory of Fiction Study. Yogyakarta: Gajah Mada University Press.

[5] Prasetya, HB; Timbul Haryono; Lono L. Somatupang. 2011. Habitus, Ngeng, and Aesthetic Mleset and Nggandhul Sounds in Karawitan. Journal of Cultural Studies Paradigm.

[6] Ratna, I Nyoman. 2004. Literary and Cultural Studies: Representations of Fiction and Facts. Yogyakarta: Learning Library.

[7] Siahaan, Nalom.1982. Adat Dalihan Na Tolu: Principles and Implementation. Jakarta: Tulus Jaya.

[8] Sihombing, T.M. 1986. Batak Philosophy: About Customs Customs. Jakarta: Balai Pustaka.
[9] Sitanggang, JP (2014). Batak Na Marserak (Scattered Batak People). King of NaPogos. Jakarta.

[10] Sugiono. 2009. Quantitative, Qualitative, and R\&D Research Methods. Bandung: Alfa Beta.

[11]Sumawo, Wiji. 2006. Fundamentals of Educational Sciences. Jogjakarta: Ar-ruz Media

[12] Uhbiyati, Nur. 2007. Education. Jakarta: PT Rineka Cipta.

[13]Zuriah, Nurul. 2008. Moral Education and Character in Change Perspective. Jakarta: Earth Literacy. Dissertation

[14]Hodges, William Robert Jr. 2009. "Change Andung Gabe Ende (ReplacingLament, Becoming Hymns): The Changing Voice of Grief in the Prefiberative Wakes of Protestant Toba Batak (North Sumatra, Indonesia)", [Dissertation] University of California Santa Barbara 